\title{
The deep error of political libertarianism: self- ownership, choice, and what's really valuable in life
}

\author{
Dan Lowe (iD) \\ Department of Philosophy, The University of Colorado, Boulder, USA
}

\begin{abstract}
Contemporary versions of natural rights libertarianism trace their locus classicus to Robert Nozick's Anarchy, State, and Utopia. But although there have been many criticisms of the version of political libertarianism put forward by Nozick, many of these objections fail to meet basic methodological desiderata. Thus, Nozick's libertarianism deserves to be re-examined. In this paper I develop a new argument which meets these desiderata. Specifically, I argue that the libertarian conception of self-ownership, the view's foundation, implies what I call the Asymmetrical Value Claim: a dubious claim about the importance of choice relative to other valuable capacities. I argue that this misunderstands what is really valuable in life, and show how it causes libertarianism to generate counterintuitive public policy recommendations.
\end{abstract}

KEYWORDS Libertarianism; Nozick; Robert; self-ownership; public policy; methodology

\section{Introduction: the case for revisiting Nozick's libertarianism}

Robert Nozick's Anarchy, State, and Utopia (1974) by no means invented the political philosophy of libertarianism, but it provided the most solid foundation the view had then seen. Nozick's libertarianism rests on a far more plausible normative basis than some other forms of libertarianism, such as Ayn Rand's (1961) popular but untenable ethical egoism. It also avoids staking a position in controversial economic matters, such as Milton Friedman's (1962) claims that market regulations have bad economic consequences and can even lead to totalitarianism. Indeed, Nozick's libertarianism can entirely avoid such controversial commitments, since on that view what rules out redistributive taxation (for instance) is not any determinate prediction about the economic consequences of redistribution, but rather that redistribution violates our natural right to property. ${ }^{1}$ This natural right to property is based on a simple and intuitive idea of individual self-ownership, ${ }^{2}$ an idea which continues to generate a sophisticated literature. ${ }^{3}$ 
Yet Nozick's theory can also be puzzling: despite its broadly plausible foundations (Cohen, 1995, pp. 69-70), the public policy which follows from those foundations is seen by many as counterintuitive and unappealing. This has led to innumerable critiques of the view, a full survey of which is beyond the scope of any single paper. While some of these criticisms have real merit, many have not fully appreciated the resilience of libertarianism, and on balance I think we are still waiting on a fully adequate critique of Nozick's view. Indeed, some of these criticisms, recited in both journals and textbooks as the canonical responses to libertarianism, fail to meet some basic methodological desiderata. It is worth briefly mentioning these desiderata to see how difficult a truly satisfactory critique of libertarianism is-and what sort of critique might move the debate forward productively.

The first desideratum is obvious enough: a forceful critical argument must not beg the question by relying on reasons the plausibility of which the opponent's position rules out. ${ }^{4}$ Yet many critiques do just that by adopting a common argumentative strategy: trying to show that libertarianism fails to give acceptable content to the most central concepts in political philosophy, such as freedom, autonomy, and rights. Consider Jonathan Wolff's (1991) argument in his book-length examination of Anarchy, State, and Utopia that Nozick's theory of rights is ultimately incoherent. Wolff argues that having so few constraints on the accumulation of wealth ends up limiting the effective rights of others (141). Wolff may well be correct about this, but he relies on positive rights to make his case-a conception of rights which libertarians reject. Wolff's case illustrates a difficulty for this general argumentative strategy. Which conception of autonomy, freedom, or rights one accepts is largely a function of the broader political worldview to which one is attracted. A Marxist will have certain conceptions of autonomy, freedom, and rights; a liberal will have rather different conceptions of each. Indeed, part of what it is to come to a coherent political worldview is to have a conception of the major values of political philosophy. Thus, arguments like Wolff's which rely on concepts like autonomy, freedom, or rights, are likely to lack force against the libertarian, for the simple reason that his very libertarianism gives him a rival conception of those same concepts. ${ }^{5}$ Many of the canonical objections to Nozick's libertarianism rely on the central concepts in political philosophy, and are thus at risk of begging the question. ${ }^{6}$

The second desideratum is that a truly powerful objection will not just demonstrate a weakness in a position, but show what is deeply wrong with it. Consider Will Kymlicka's (2002) articulation of the familiar objection that Nozick's theory of property is unworkable, since we usually have no way to tell whether one's holdings were justly acquired or transferred throughout the entire chain of transfer-and even when we do know that holdings were transferred unjustly, their rightful owners are often unknown (111-112). This 
is a persuasive objection and a genuine problem for libertarianism. But for all its force, it does not get to the heart of the matter; the main thing keeping egalitarians from becoming libertarians is surely not the epistemic problems associated with chains of ownership. ${ }^{7}$ Consider now the numerous counterexamples leveled at libertarianism. In his popular textbook, Michael Sandel (2009) notes that a consistent libertarian state would allow an eccentric art dealer to buy a person's kidney to mount as a conversation piece, and would do nothing to restrict even consensual cannibalism (71, 73-47). These counterexamples are evocative, and may pose a genuine problem for Nozick's view. But even the most powerful counterexample cannot pinpoint the deep error of a complex theory; it is a natural extension of the Duhem-Quine thesis to say that counterexamples can only show that something, somewhere in the theory has gone wrong (Quine, 1951). This kind of critique leaves undetected any deep error in a theory.

Of course, there is some consensus among egalitarians about the nature of the deep problem with libertarianism. Simply put, libertarianism gives too much importance to individual choice at the expense of other important social values. This is ultimately the conclusion that I favor; but even if this diagnosis is correct, it is not particularly illuminating. That libertarianism is concerned primarily with individual freedom is simply a slogan, and saying that it's too concerned with freedom is merely to sloganize its rejection. Such an articulation of the deep error of libertarianism is too impressionistic and in need of rigorous argument to be persuasive.

Nozick's libertarianism, then, is more resilient than many canonical egalitarian critiques give it credit for. A fully adequate critique of libertarianism has to include two virtues, in addition to the obvious one of soundness: it must avoid begging the question, and it must diagnose the deep problem with libertarianism. This paper revisits Nozick's libertarianism to provide such a critique, and at the same time tries to gives some precision to the impressionistic claim that libertarianism overvalues individual freedom. The focus here is on Nozick because a great deal of contemporary natural rights libertarianism traces its heritage to the locus classicus of Nozick's work-though it must be cautioned that the critique here does not thereby apply to every single form of contemporary natural rights libertarianism. The critique claims that the deep error of Nozick's libertarianism is to be found within the apparent heart of its appeal: the libertarian conception of self-ownership. ${ }^{8}$ This conception of self-ownership lends itself to misunderstandings, and once its real commitments are seen clearly, its appeal should largely fade. ${ }^{9}$ Specifically, I argue that the libertarian conception of self-ownership implies what I call the Asymmetrical Value Claim: the claim that the value of the capacity of choice is radically different from the value of all other capacities. I argue that such a view is mistaken about what is really valuable in life. 
I noted at the outset that for many, libertarianism constitutes a puzzle. One possible way to resolve the puzzle would be to show that self-ownership is not nearly so appealing as it might seem. If there is indeed a problem with the libertarian conception of self-ownership, then the fact that the theory generates counterintuitive policy recommendations is no longer surprisingindeed, it ought to be expected.

\section{The target of critique: the libertarian conception of self-ownership}

Because the content of Anarchy, State, and Utopia is by now so familiar, I provide only the most selective overview, but luckily the core argument can be put quite simply. As I noted, most scholars now agree that the foundation of Nozick's view is the libertarian conception of self-ownership. ${ }^{10}$ The thesis of self-ownership states that each person fully owns him- or herself. Michael Huemer (2015) elucidates the meaning of this claim by comparison with other forms of ownership: 'A person has the right to exercise control over his own body-including the right to how it should be used, and to exclude others from using it-in a manner similar to the way one may exercise control over one's (other) property' (424-425).

As Huemer indicates, the thesis of self-ownership is a claim about what rights one has. Accordingly, one's conception of self-ownership is determined by one's conception of what it is to have a right to something. The libertarian conception of rights is composed of three theses:

1. Rights are fundamentally natural. A person has the rights associated with selfownership just because one is a person, not because such rights are somehow invented or constructed by a given society. Of course, this does not mean that persons cannot have conventional legal rights-but only that such rights must be derivative from natural, more fundamental rights.

2. Rights are fundamentally negative. The right to life, for example, means that it's wrong to take someone's life-not that one has a right to be given the resources necessary to live. Again, this does not mean that persons cannot have positive rights to, say, police protection-but only that such rights must be derivative from negative, more fundamental rights.

3. Rights are fully deontological. Rights are a moral category independent of utility, and cannot be violated for the sake of an overall utility gain. ${ }^{11}$

Putting the pieces together, persons have a natural, negative, and fully deontological ownership right over themselves. Call this the libertarian conception of self-ownership.

The libertarian conception of self-ownership generates a substantial schedule of rights with determinate content. Because I own myself, I have a right to life, just as when I own my water bottle I have a right to prevent it from being destroyed. It is easy to see how this point extends naturally to other rights like those of bodily integrity, freedom from slavery, and still others. 
The libertarian conception of self-ownership leads in a straightforward way to characteristically libertarian public policy. If I have an ownership right over myself, and you have an ownership right to a certain sum of money, then we have a right to exchange my labor for your money. ${ }^{12}$ Yet if the law requires a minimum wage, the state may prevent this transaction from occurring. Since the primary requirement for a just state is that it does not violate rights, a just state may not have a minimum wage, either to prevent the transaction from occurring in the first place or overturning its terms once it has been agreed to.

Many considerations which usually tell in favor of policies like a minimum wage are ruled out by the libertarian conception of self-ownership. A minimum wage cannot be justified on libertarian grounds by saying that one only has a right to exchange within a certain social framework which requires a minimum wage, since for the libertarian rights are fundamentally natural, and exist independently of one's membership in society. Nor can it be justified by saying that a person is entitled to a living wage, since for the libertarian property rights are fundamentally negative, not positive. It also cannot be justified by saying that an individual or society as a whole would be better off if there were a minimum wage, since for the libertarian rights are fully deontological, and cannot be sacrificed for a utility gain. Nor can a minimum wage be justified on grounds that employers have a moral obligation to give their employees decent wages, since even if such an obligation exists, it does not follow from the fact that I have a moral obligation to do something that the state may permissibly force me to do it. ${ }^{13}$ It is easy to see how similar arguments could be mounted for typically libertarian policies such as a prohibition on redistributive taxation. ${ }^{14}$

However much sense this view of the state makes within the libertarian theory, many find this picture of the minimal state to be quite unattractive. The prospect of abolishing any state protections whatsoever for wage levels or the welfare of the very poor looks to most people more like dystopia than utopia. Indeed, even among libertarians, Nozick's view is rather extreme, since many libertarians favor at least some (albeit minor) role for the state in maintaining the social welfare through some (albeit minor) redistribution (e.g. Friedman, 1962). If critics of libertarianism are right to find such public policy unsatisfactory, then where is libertarianism supposed to have gone wrong?

\section{The deep error of libertarianism}

\section{A counterexample to libertarianism}

One of the classic objections to libertarian policies such as the elimination of the minimum wage is that they do not take into account how the parties 
transacting may be differently situated. Consider, for instance, the following counterexample to libertarianism adapted from one by G.A. Cohen (1995, p. 54) which highlights the limits of libertarian respect for rights of contract and property.

Escape: You are sailing when your boat encounters a storm and sinks. After several days of clinging to driftwood, you wash ashore on an island, nearly dead from lack of water and nutrition. An inhabitant, Jenny, offers to go retrieve some of the island's food and water that you need to survive - but only if you are willing to become her slave for life. She assures you that, although the life of slavery will be bad, it will not be so bad that you would prefer death. You agree, and she holds up her end of the bargain: although you are her slave, she gives you a quality of life which is (perhaps just barely) preferable to death. But after six months of enslavement, you find an opportunity to escape the island. You do so, leaving your slaveowner behind.

While it is morally wrong for Jenny to offer such a contract to you, Nozick (1974) argues that it violates no one's rights to sell oneself into slavery (331). One's ownership in oneself allows one to relinquish that rightful control of oneself to another, just as one's ownership of one's water bottle allows one to relinquish that water bottle to another. (Not all in the libertarian tradition accept the legitimacy of voluntary slavery [e.g. Locke 1980, Ch. 4], so for them the case can be weakened to a contract requiring some years of indentured servitude; the difference does not much affect the force of the counterexample).

Once the contract is established, libertarian justice requires that the contract be maintained. It is irrelevant that the parties are very unequally situated - Jenny is comfortable while you are on the verge of death-since that is just as true in the case of the minimum wage, where comfortable capitalists contract with proletarians who may die if they do not work. ${ }^{15}$ Yet it seems clear that in escaping the slaveowner you do not act wrongly, even though you break the terms of your contract and thus allegedly violate her property rights. ${ }^{16}$ And perhaps more importantly, if someone (or the government of the island) sought to prevent your escape, they would be acting wrongly, even though they would be enforcing Jenny's alleged property rights. But the libertarian judges that Jenny's property rights give her a legitimate claim on your labor, and a just state would enforce such a claim.

As I noted earlier, counterexamples can only show that something, somewhere in a theory has gone wrong. But the case just described can help point us in the direction of the deep error within libertarianism.

\section{What the libertarian conception of self-ownership really amounts to: the asymmetrical value claim}

The deep error that generates the counterexample is the libertarian conception of self-ownership. Because the libertarian conception of self-ownership is 
fundamentally a set of claims about rights, I argue that once the content of libertarian rights is unpacked with sufficient precision, libertarian selfownership should lose much of its appeal. Moreover, because the argument here aims to give some precision to the consensus among egalitarians that libertarianism overvalues individual choice, the argument centers on a connection between rights and values.

One account of the connection between rights and values comes from Charles Taylor (1985, p. 195), who notes a general feature of rights claims: every right corresponds to some valuable capacity - whether it is a capacity the right protects (in the case of negative rights) or nurtures (in the case of positive rights). For instance, the right to life protects the capacity to live; likewise, the right to freedom of speech protects the capacity to express oneself. Specific examples aside, why think such a principle would be true generally? As Taylor puts the point, '...there would be something incoherent and incomprehensible in a position which claimed to ascribe rights to [persons] but which disclaimed any conviction about the special moral status of any human capacities whatever and which denied that they had any value and worth...' (195). Taylor puts the point quite strongly in terms of the coherence of the concept of rights. We do not have to go quite that far; we can simply say that the concepts of rights and capacities are connected deeply enough that someone who claimed that persons had a right to life, but that life was not generally valuable at all, would be making a very eccentric claim.

In short, for any right, that right protects some valuable capacity; let us call this Taylor's Thesis. The libertarian schedule of rights mentioned earlier includes the rights to life, bodily integrity, and autonomy. And in conjunction with Taylor's Thesis, this seems to yield the quite plausible claims that life, bodily integrity, and autonomy are valuable capacities. And likewise, the libertarian conception of self-ownership seems to entail that killing someone, maiming them, or enslaving them violates their rights. But, strictly speaking, this isn't so-indeed, this is a crucial way in which libertarian self-ownership lends itself to misunderstandings.

To see why, recall that these rights are conceived of on the model of ownership rights. My ownership right over a water bottle does not actually entail that it is wrong for you to drink from it, take it home, or even destroy it -my ownership right means that it is wrong for you to do these things without my consent. Likewise, according to the libertarian conception of selfownership precisely understood, killing someone, maiming them, or enslaving them are not necessarily rights-violating, but only so if the person has not given their consent that happen. This comes through in characteristic libertarian positions such as support for assisted suicide.

Given this more precise understanding, Taylor's Thesis implies something far more interesting. Indeed, it yields the first key point on the way to 
understanding the deep problem with libertarianism: the capacity to choose whether to give one's consent or not is in fact the only capacity protected by libertarian rights. My right to life, for instance, by no means protects my capacity to live if I choose not to live. Accordingly, self-ownership merely specifies the domain in which the capacity of choice is to be respected, such as the domain of one's own bodily integrity. After all, it is not in every domain that consent must be respected, but only the ones circumscribed by libertarian rights. Self-ownership-which says that one must receive your consent to end your life, maim your body, or enslave you-only indicates with respect to what domain one must receive consent to avoid violating rights.

The second key point emerges once we recall that libertarian rights are fully deontological. In other words, whatever else is valuable in the world, morally or prudentially, can only be permissibly pursued once rights are respected (see also Dworkin, 1984; Steiner, 2013). Here Nozick's terminology of deontological prohibitions as 'side constraints,' though somewhat oldfashioned, is quite apt. Consider again the libertarian stance on redistributive taxation. Libertarians need not make the claim, put forward by some conservatives, that redistribution is bad for those who receive it, insofar as it corrupts them morally or prudentially (by removing incentives which would encourage them to live a better life). Libertarians can accept that there is value to be had in redistribution-plausibly, moral value for the giver and prudential value for the receiver. But the libertarian's position is that redistribution, regardless of what value it may have, violates one's (property) rights, and is thus ruled out by a just state. This is the second key point to grasp: according to the libertarian conception of self-ownership, rights must be respected before all other values are to be realized.

While each of these ideas appear innocuous on their own, their combination constitutes the deep error of libertarianism. The first key point is that the capacity for choice is the only capacity protected by libertarian rights. The second key point is that libertarian rights must be respected before all other values are to be realized. And so it follows from these two points that, for the libertarian, the capacity of choice is protected before all other values are to be realized.

This is so even when these values are associated with the protection or development of other important capacities. This means that the capacity of choice is not simply strongly protected, but enjoys a lexical protection with respect to all other values and capacities. It is easy to misunderstand what is being said here. This argument does not claim that the libertarian is committed to the highly implausible claim that the capacity of choice is the only valuable capacity that there is; it is simply the only capacity protected by libertarian rights. Nor does the argument claim that the libertarian is committed to the platitudinous claim that the capacity of choice is very valuable. Rather, because the capacity of choice enjoys a lexical protection compared 
to all other capacities, the libertarian is committed to the claim that there is a radical asymmetry between the value of the capacity of choice and the value of all other capacities. Call this the Asymmetrical Value Claim.

The derivation of the Asymmetrical Value Claim is the first step in providing a rigorous argument for the impressionistic claim that libertarianism is too concerned with individual choice. The Asymmetrical Value Claim may seem highly implausible on its face, but it is worth taking the time to explain what, specifically, is wrong with it.

\section{What's wrong with the asymmetrical value claim}

To begin, it is worth considering the odd, even extreme position the Asymmetrical Value Claim has within the pantheon of philosophical traditions. It is extreme, first, in what value it regards as primary. Various philosophical traditions have extolled a number of human capacities-reason, virtue, authenticity, happiness, and still more, but few have singled out choice in the way that libertarianism has.

Second, libertarianism is extreme in how it interprets the value of choice, where it is construed as a matter of explicit consent. The narrowness of this conception of choice contrasts dramatically with other political theories which emphasize all the other, more subtle ways in which one's capacity for choice can be constrained or distorted, as when the options for choice are severely limited or when the preferences one is choosing based on are adaptive. Libertarianism regards these phenomena not so much as being unreal, but rather as basically irrelevant to its conception of choice.

Third, libertarianism is extreme in how this narrowly interpreted primary value relates to the vast array of secondary values. In many philosophical traditions it is common to privilege some values over others, but rarely is that privileging as stark as protecting only one capacity through enforceable rights. ${ }^{17}$ Likewise, within many philosophical traditions it is common to see choice as a central capacity and value. But the problem with the Asymmetrical Value Claim is not that it sees choice as very valuable, or even as intrinsically valuable. Rather, the claim that choice is intrinsically valuable is quite far from the claim that choice enjoys a radically different status from all other capacities.

To be sure, the capacity for choice is (often) prior to other capacities in a physical or metaphysical sense. That is, making a choice with regard to something (e.g. choosing to read a certain novel) is often necessary for being able to use or develop other capacities (e.g. one's capacities for narrative imagination and empathy). But metaphysical priority does not entail axiological priority. It may be necessary for me to sit in traffic in order to go see my friend and exercise my capacity for friendship. But it does not follow that sitting in traffic is just as valuable as the capacity for friendship, and it 
certainly does not follow that sitting in traffic is radically more valuable than the capacity for friendship. Even when the means are utterly necessary-as choice is for realizing some kinds of value-it does not follow that the means are more valuable than the ends, only that they are practically required.

This illustrates why the Asymmetrical Value Claim is not just extreme, but misguided. Even if the capacity for choice is intrinsically valuable, we generally (though not always) choose in order to gain some other value, to develop or actualize some capacity other than the capacity for choice. Yet according to the Asymmetrical Value Claim, it is choice which has a radically privileged status with respect to all other capacities. It is true that we are fundamentally beings who choose. But we are just as fundamentally beings who choose for the sake of realizing other kinds of value. To privilege one aspect of our nature so radically over the other is to misunderstand what is really valuable in life. The Asymmetrical Value Claim is more than just prima facie implausible, it misunderstands the value of choice: The Asymmetrical Value Claim fetishizes the capacity of choice, while undervaluing the capacities which partially give choice its importance. ${ }^{18}$

\section{The counterexample revisited}

I noted earlier that counterexamples to libertarianism are of limited usefulness in assessing the theory, since they do not by themselves constitute the deep problem with the theory. But now that we have identified the Asymmetrical Value Claim as the deep error, we can see how this generates the kinds of counterexamples that are so often leveled against libertarianism. Let us reconsider Escape. A consistent libertarian would deem your escape from your slaveowner to be a violation of her rights, and would endorse the coercive power of the state to maintain the terms of such a contract. The Asymmetrical Value Claim reveals why the libertarian is committed to this judgment.

The libertarian is so committed because the contract represents two persons' choices (with respect to their labor power), and the only capacity protected by the libertarian conception of self-ownership is the capacity for choice. Hence, the contract itself, the representation of those choices, is protected. That contract may impede the development of a host of other valuable capacities-Jenny's moral capacities, and the capacities you could actualize once you are free. But because there is a radical asymmetry in the value of the capacity of choice and the value of all other capacities, those capacities weigh nothing against the contract, and so they are sacrificed on the altar of respect for choice.

This respect for choice is actually a fetishization. Your capacity for choice is not merely an instrument for locking you into ironclad contracts; it is at least partly a route by which you achieve what is really valuable in life. The 
Asymmetrical Value Claim misses the fact that your capacity for choice is valuable partly because it allows you to develop and actualize those other capacities.

\section{The upshot of the argument}

As I noted in the introduction, there is some consensus among egalitarians about what libertarianism gets wrong: it puts too much importance on individual choice and too little importance on other social values. The argument here brings such a claim into more precise relief, and provides a rigorous basis for the claim itself. It also helps make sense of why counterexamples like Escape are generated, where important goods are sacrificed on the altar of respect for choice. And finally, the argument here helps us resolve the puzzle mentioned at the outset: how can a view whose foundations seem so plausible lead to such counterintuitive public policy? We can now see that the problem is not in some subtle but fallacious move from libertarian foundations to public policy conclusions. The problem is in the foundations themselves.

\section{Objections and replies}

\section{Does libertarianism really give priority to the capacity of choice?}

I noted in the introduction that a satisfactory critique of libertarianism would have to meet two basic methodological desiderata: diagnosing the deep problem with libertarianism, and not begging the question against the libertarian. Here I examine objections to my diagnosis of the deep problem, that libertarianism implies the Asymmetrical Value Claim, an extreme form of priority for the capacity of choice. ${ }^{19}$

One worry about this diagnosis is that one can seem to violate a person's libertarian rights in choice-enhancing ways. Suppose, for instance, that neuroscientists develop a serum that can significantly enhance one's capacity for choice, and try it out on unsuspecting and unwilling test subjects. The unethical scientists thereby violate their subjects' self-ownership, since they do not obtain their consent. Let us grant for the sake of argument that the subjects' capacity for choice is also enhanced; since the libertarian (rightly) regards such treatment as a violation of rights, how can libertarianism reflect a fetishization of choice?

Here we must distinguish between two ways in which a normative theory might privilege one value over others. One way is to maximize the value, which is consistent with violating that value at one time if it leads to more of the value at a later time. Another way is to give the value lexical priority, where the value may not be violated even for the sake of more the very same 
value later. The unethical scientists maximize the test subjects' capacity for choice, but they don't prioritize it, because they inject the subjects without obtaining their consent. Libertarianism similarly prioritizes consent without maximizing it, since one may not violate a person's rights in order to prevent that person's rights from being violated in the future (Nozick, 1974, pp. 28-29). This is why libertarianism renders the judgment it does about the case of the unethical scientists. Accordingly, libertarianism reflects the privileging of choice, so long as we understand the privileging as having a lexical and not maximizing form.

Even if one admits that libertarianism privileges the capacity of choice in this way, what about the claim that in doing so the libertarian misunderstands what is really valuable in life? One natural place to push back is that no one would voluntarily enter into a contract such as the one in Escape unless one thought it was necessary to secure what is really valuable in life.

There is something right in this; the decision to enter into the contract is probably prudentially rational, since one cannot pursue anything valuable whatever if one is dead. However, the problem for the libertarian is less in entering the contract than exiting it. At that later time, escaping and thereby violating the terms of the contract is not just prudentially rational, but morally acceptable. Yet libertarianism judges such an act to be an unacceptable violation of rights. It is this judgment which reflects the Asymmetrical Value Claim. Whatever capacities you might exercise after escaping are trumped by respect for the contract, and so the libertarian's judgment reflects the privileging of choice over all other capacities. This is consistent with the idea that there are times-such as entering the contract-where choosing goes together with exercising (and in this case, continuing to have) other capacities. The difficulty arises with the libertarian's moral judgment that in Escape, when the two come apart, respect must be given to the capacity of choice alone.

Finally, even when we focus exclusively on the libertarian's judgment about the act of escape, there are worries about whether the above diagnosis correctly identifies what is wrong with the libertarian's judgment. We can easily imagine a variant of Escape where the contract specifies that you will have no choice but to develop a whole host of your capacities, to an even higher degree than you would if you had not become a slave. You might be forced, for example, to learn to play the piano and write novels and master a practical craft. Whatever the details, it would also be wrong for the state to enforce this variant of the contract. Yet it seems that my preferred diagnosis of the libertarian's error in such a case cannot be right, since ex hypothesi this contract involves the significant development of a number of capacities. So why think that the deep error of libertarianism is that it prioritizes the capacity of choice over all other capacities? 
It is true that in the variant case the contract itself involves the development of a whole host of capacities. However, notice that the libertarian's judgment about the contract is made independently of those provisions. Indeed, the libertarian would enforce both the original contract and the variant precisely because the particular provisions are irrelevant to the libertarian (assuming none involves the violation of rights of a third party). All that is relevant is that the contract is agreed to voluntarily (keeping in mind that, for the libertarian, the voluntariness of the contract is not undermined by the unequal standing of the contractors). And so if we grant, as the example does, both (a) that the variant contract is unjust, and (b) the consensual nature of the contract is sufficient for the libertarian to defend it, then it is hard to avoid the conclusion that the libertarian overstates the importance of choice, taking it to be sufficient for the justice of the contract when it is not.

But if the libertarian overstates the importance of choice, does he do it at the expense of other important capacities? When thinking about slavery contracts it is hard not to see the injustice of such contracts as lying in the stifling of a number of other capacities, even when evaluating the variant case. For instance, if we maintain a psychologically realistic account of what slavery is actually like, then any of the capacities associated with happiness and well-being are likely to be stunted. ${ }^{20}$ This is true regardless of one's preferred theory of welfare: a hedonist will be able to say that the slave is inhibited from exercising their capacity for pleasure; a desire satisfactionist can say that the slave is inhibited from exercising capacities that they desire to exercise; and so on. And while a slaveowner may command one to develop and exercise a number of capacities, the capacities associated with well-being are difficult to exercise through coercion, at least significantly. Human psychology being what it is, one can command someone to harvest crops in a way one cannot command them to enjoy a piece of art.

This is just one example, and it is not meant to rule out alternative accounts of the injustice of slave contracts. After all, the wrongness of enforcing a slave contract is probably highly overdetermined. Accounts of the wrongness of American slavery, for example, emphasized not just the theft of the products of one's labor, but also the material deprivation and unhappiness faced by slaves, the way slave families were torn apart by the institution, the treatment of the human being as a mere means to the ends of another, as well as the underdevelopment of the slave's faculties (Basker, 2012). When one considers all of the ways in which slavery is wrong, it is hard not to think that at least some aspects of the wrongness of slavery run through the stunting of the slave's capacities. ${ }^{21}$ Since such conditions are likely to exist even in slave contracts, and since the libertarian neglects these wrongmaking features by focusing solely on the consensual nature of slave contracts, the libertarian does indeed prioritize choice unduly over other capacities. 


\section{Does the argument beg the question against the libertarian?}

Now let us consider the second methodological desideratum, that the argument not beg the question against the libertarian. I have claimed that arguments which depend on central concepts in political philosophy have tended to beg the question because what differentiates rival schools of political thought are rival conceptions of those central concepts. By contrast, the derivation of the Asymmetrical Value Claim is not put in terms of concepts like equality, freedom, or legitimacy, but rather values and capacities-concepts which do not generally demarcate rival schools of political thought. However, the argument also involves claims about rights, and rival schools of political thought often are divided based on their conceptions of rights.

There is, for instance, the longstanding debate between the Interest Theory and the Will Theory of rights (Kramer, Simmonds, \& Steiner, 1998). According to the Interest Theory (roughly stated), the function of rights is to protect the interests of rights-holders. According to the Will Theory (again, roughly stated), the function of rights is to protect the ability of rights-holders to exercise their will in various domains. It might seem that Taylor's Thesis, that for every right there corresponds some valuable capacity, is redolent of the Interest Theory, which states that for every right there corresponds some sufficiently strong interest. The worry is that not merely that the debate is unsettled, and that Interest Theory of rights is therefore controversial; the problem is also that the Interest Theory of rights is typically rejected by libertarians. ${ }^{22}$ After all, if rights correspond to interests, then it is plausible that persons have a great many interests -in education, health care, and a living wage-which libertarians do not admit as rights.

It is true that if Taylor's Thesis presupposed the Interest Theory, then the argument would beg the question. However, some quick clarifications will show that it does not. For the sake of argument, let us grant the contention that valuable capacities are strongly connected with the interests of those with such capacities; this will allow us to talk about Taylor's Thesis as being about interests rather than valuable capacities. In that case, Taylor's Thesis implies that for every right there is a corresponding interest. The Interest Theory of rights says that for every interest there is a corresponding right. The contrast between the claims is in the direction of entailment, and this makes all the difference.

It is not the entailment of interests from rights which is objectionable to the libertarian, but the reverse, the entailment of rights from interests. If interests generate rights, then this opens the door to paternalism, since if I act against your will to protect your interests, I have ex hypothesi not violated your rights. If interests generate rights, then this creates the problem of third party beneficiaries. (Briefly, the problem is this: If two parties, $A$ and $B$, contract to provide some benefit to $C$, then on the Interest Theory, $C$ has a 
right to the fulfillment of the contract, since it is in $C^{\prime}$ 's interest that the contract be fulfilled. But intuitively, A and B may agree to dissolve the contract without consulting C.) And most importantly, if interests generate rights, then the variety of strong interests leads to the proliferation of positive rights to which libertarianism is so deeply opposed.

The reverse entailment, of interests from rights, is by contrast a quite modest claim. Enumerate whatever schedule of rights you find plausible, and all Taylor's Thesis would commit you to is that those rights-whatever they are-correspond to valuable capacities. Nothing in either the Will Theory or the Interest Theory makes such an implication implausible. Thus, far from begging the question against one side in the debate, Taylor's Thesis represents a rare area of overlap between otherwise radically different theories. ${ }^{23}$

\section{Can a more moderate version of Nozick's libertarianism avoid the critique?}

The argument that the libertarian conception of self-ownership implies the Asymmetrical Value Claim turned crucially on the idea that libertarian rights are fully deontological, meaning that one cannot violate another person's rights for the sake of an overall utility gain. After all, if the protection of the capacity of choice were not fully deontological, then in cases like Escape the value that comes from violating the contract might outweigh the value of maintaining the contract. Of course, conceiving of rights as fully deontological is plausible when the prospective overall utility gain is quite modest. But this seems altogether too strong in cases where there is a very large difference in utility-cases like Escape. Nozick (1974) famously tried to avoid this issue; in a footnote, he wrote that 'The question of whether these [rights] are absolute, or whether they may be violated in order to avoid catastrophic moral horror, and if the latter, what the resulting [moral] structure might look like, is one I hope largely to avoid' (30 n.) The intervening years have shown that the question cannot be avoided. It is now generally accepted that a plausible version of deontology will include some caveat, often called a 'disaster-avoidance clause,' which is supposed to accommodate cases where we intuitively think that considerations of utility are outweighing (e.g. Hooker, 2003, p. 98).

A less extreme version of Nozick's theory of rights, which incorporated a disaster-avoidance clause, would seem to affect the soundness of the argument I've laid out, since it would mean that Nozick's theory was no longer fully deontological. However, there are at least two importantly different interpretations of the disaster-avoidance clause, and which one is to be incorporated into Nozick's theory will make a difference for how best to evaluate that theory. 
The most straightforward way to understand the disaster-avoidance clause is that what counts as a disaster is specified in absolute terms. In other words, there is some absolute threshold of disutility, above which an event or state of affairs counts as a disaster. This presumably captures what Nozick meant by 'catastrophic moral horror,' and makes sense of why some think that it is morally acceptable to, say, torture someone in a ticking time bomb case where hundreds of thousands of lives are at stake.

It is true that, if the absolute interpretation of the disaster-avoidance clause were incorporated into the libertarian conception of self-ownership, this would make some difference in the foregoing critique. For one, libertarianism would no longer imply the Asymmetrical Value Claim as it is-the capacity of choice would no longer enjoy its privileged place over all other capacities just in case disregarding that choice could avert a disaster. But the extreme abnormality of cases like the ticking time bomb is relevant here. There are, after all, extraordinarily few circumstances in which this caveat would actually come to bear-indeed, in the vast majority of persons' lives, the disaster-avoidance clause so understood would probably never be invoked. And so the value of choice would remain privileged compared to the value of all other capacities in almost every situation. Indeed, this new, slightly more moderate version of libertarianism would generate nearly all the same counterexamples as the old version. As a case in point, it would still render the same verdict in Escape, since the lifetime of slavery would not come near the absolute threshold of disutility. Thus, in practice the deep error of libertarianism would remain, inasmuch as the capacity for choice would still enjoy far too much respect. Although the absolute interpretation is the most straightforward way of understanding the disaster-avoidance clause, incorporating it does little to help the libertarian.

An alternative interpretation of the disaster-avoidance clause is that what counts as a disaster is proportional to the importance of the right being infringed upon (Thomson, 1992, p. 151). For example, if I could (somehow) save a child's life by destroying your houseplant without your consent, such an action would be morally acceptable. Although one child's death is not a disaster in the absolute sense specified earlier, it would nevertheless be a disaster for a child to die so that a houseplant might live. This interpretation has the added virtue of accommodating the intuitions which motivated the absolute interpretation, such as the ticking time bomb. Regardless of whether the disutility reaches a certain absolute threshold, the loss of hundreds of thousands of lives would be a (proportional) disaster compared to the harm imposed by a single act of torture.

Because this interpretation allows for a more substantial revision of Nozick's theory of rights, it does more to resist the critique. First, this new libertarian conception of self-ownership would imply something quite different from the Asymmetrical Value Claim, since there would be a number of capacities and 
values which might trump the capacity for choice, given a variety of practically possible situations. Second, the libertarian would no longer render the same verdict in Escape. Being forced to live a lifetime of servitude to another simply to avoid violating the terms of a contract would be a (proportional) disaster, and so escaping from the island would be acceptable.

But avoiding these difficulties comes at the price of veering so far from the initial libertarian theory that this new theory is unable to support some of the most basic libertarian public policy prescriptions. Consider children unable to afford basic medical care or get a decent education while the very rich are able to maintain summer homes and yachts. These children's plight would constitute a disaster, on the proportional interpretation, when contrasted with the money that could be taken from the rich while impacting their lifestyle only minimally. Or consider workers who are paid a pittance for companies with enormous profits. Workers' inability to support themselves and their families, despite working exhausting hours at tedious jobs, would constitute a (proportional) disaster compared to the marginal utility gained by the executives and shareholders who employ these workers. ${ }^{24}$ Of course, redistributing in these cases would represent a move to the left from even the status quo in this country, which is already well to the left of the state libertarians argue for. In other words, the libertarian who incorporates a proportional interpretation of the disaster-avoidance clause can avoid the critique I've made here only at the expense of his very libertarianism.

Incorporating a disaster-avoidance clause into libertarianism is an appealing move, but such a clause is ambiguous. If one adopts the absolute interpretation, this does little to avoid the critique I've made here. If one adopts the proportional interpretation, it can avoid the critique only by abandoning anything recognizably libertarian about the view.

\section{Conclusion}

I have argued that the libertarian conception of self-ownership implies the claim that there is a radical asymmetry in the value of the capacity of choice and the value of all other capacities. But such a claim misunderstands the value of choice, which is given its importance partially because of all the other capacities which choice allows us to actualize and develop. Once we grasp how the libertarian conception of self-ownership fetishizes choice, we can see not only why libertarianism leads to unsatisfactory public policy recommendations, but why libertarianism itself is unsatisfactory. ${ }^{25}$ 


\section{Notes}

1. This does not mean that Nozick's theory involves no empirical commitments. Nozick does make empirical claims about the positive consequences of libertarianism in the little-read third part of Anarchy, State, and Utopia, in which he claims that the minimal state provides a 'framework for utopia.' Nevertheless, Nozick assiduously avoids presupposing empirical claims about the positive economic effects of free markets, thus distinguishing his argument for libertarianism from more traditional arguments.

2. Notoriously, Nozick himself almost never mentions self-ownership, though his sole discussion of it is highly suggestive: 'End-state and most patterned principles of distributive justice institute (partial) ownership by others of people and their actions and labor. These principles involve a shift from the classical liberal notion of self-ownership to a notion of (partial) property rights in other people' $(172$, emphasis in original). Brief though this comment is, it indicates that selfownership plays a key role in distinguishing Nozick's libertarianism from other views, and thus occupies a central place in the theory itself. Later scholars have generally agreed that self-ownership plays a central role in Nozick's theory: see Cohen (1995), Wolff (1991), Okin (1989), Ch. 4, and Vallentyne and van der Vossen (2014).

3. In particular, self-ownership forms the shared basis of right- and left-libertarianism, which differ as to whether the world's natural resources are owned in common. In addition to Nozick, statements of right-libertarianism include Mack (2002), Feser (2005), and Huemer (2013). Statements of left-libertarianism include Steiner (1994), Otsuka (2003), and Vallentyne et al. (2005).

4. There are many views about what begging the question involves; for a list, see Sinnot-Armstrong (1999).

5. This point is anticipated, though not in such a general way, by Cohen (1995), who critically evaluates his own prior arguments about the libertarian conception of freedom $(12,67)$.

6. Here I set aside Kuhnian worries about whether any argument could avoid begging the question, if rival theories are incommensurable (Kuhn, 1962, Ch. 9 and 10).

7. Consider a group of egalitarians who set out to form a new colony from scratch on uninhabited land. Do they abandon their commitment to egalitarianism so long as they promise to keep diligent records of property acquisition?.

8. As the term 'conception' here indicates, I do not argue against self-ownership simpliciter. There is surely some sense in which the thesis of self-ownership, that each person fully owns him- or herself, is true. Self-ownership becomes contentious with the specifically libertarian conception of what it is to have an ownership right over oneself.

9. I am, of course, not the only one to argue against self-ownership. See, for instance, Cohen (1995), Ch. 10; Lippert-Rasmussen (2008); Arneson (2011); Sobel (2012).

10. Nozick (1974) does have arguments for the libertarian conception of selfownership (Nozick puts it in terms of libertarian side constraints), but these are generally agreed to be sketchy and unconvincing. One argument attempts to justify libertarian side-constraints from considerations about the meaning of life (50-51). However, Nozick himself admits that the argument here is seriously incomplete, noting, 'I hope to grapple with these and related issues on another occasion' (51). Another argument, which has received more scholarly attention, attempts to derive specifically libertarian side-constraints from the existence of deontological 
side-constraints more generally (28-35). Nozick summarizes the argument in this way: 'We have a promising sketch of an argument from moral form to moral content: the form of morality includes $F$ (moral side constraints); the best explanation of morality's being $F$ is $p$ (a strong statement of the distinctness of individuals); and from $p$ follows a particular moral content, namely the libertarian constraint' (34). One feature of this view is that it would imply that any non-libertarian form of deontology was in fact internally inconsistent, an interesting but highly controversial claim which would require much more argument than Nozick gives it. For another view of the problem with the argument, see Arneson (2011).

11. While this condition is true to Nozick's libertarianism, it will seem to many defenders and critics of libertarianism to be entirely too strong. However, the issue is not as important as it may seem. While the condition is important for the critique I offer, I do not single it out as the deep error. Nor would weakening this condition affect the cogency of the critique, as I shall argue later.

12. Some resist Nozick's argument here by noting that my ownership of things outside myself cannot be derived from my self-ownership, even if my labor power is partly what allowed me to produce or acquire them. See, for instance, Murphy and Nagel (2002). This is an important point of resistance from egalitarians, and I am sympathetic to Nagel and Murphy's approach. However, this is not the only point of resistance from egalitarians, who are also skeptical about the binding force of consent among unequally situated contractors. An advantage of my critique is that it captures both of these points, as will become clear later.

13. In other words, there can be a right to do (certain kinds of) wrong. Denying the total correlativity of rights and duties is plausible; for a classic discussion, see Feinberg (1962).

14. Of course, what makes redistributive taxation wrong on Nozick's view is not that my money is used to benefit another; it is that my money is taken without my consent. From this it is natural to wonder whether any taxation is permissible on Nozick's theory, since when the government levies taxes it is not soliciting for voluntary contributions as with a PBS telethon, but is demanding money coercively. And since taxes are necessary for the existence of a state at all, it seems like Nozick's principles commit him not to the minimal state, but to anarchism. Nozick does have a response to this argument in the lengthy first part of Anarchy, State, and Utopia. However, few find his response successful; for a critique from the left, see Wolff (1981); for a critique from the right, see Rothbard (2002), Ch. 29.

15. This is not hyperbole, since in a libertarian society there is no welfare state to prevent this from happening, and charity provides no guarantee of assistance. Of course, one might argue that unrestricted capitalism would allow for full (and adequate) employment. However, such empirical claims are controversial; again, a distinctive feature of Nozick's position is that it does not rely on empirical predictions about economics to justify his libertarianism.

16. Although this purports to be a problem for the libertarian, there is one highly creative way in which the libertarian may consistently accept such a conclusion. The case of slavery is unique because the aim of slavery is to reduce the slave to a state equivalent to that of a domestic animal; and because animals have no duties, such a slave also has no duties; hence, the slave does not act wrongly in escaping, because a slave cannot act wrongly at all. While this argument certainly invokes a guiding ideal of slavery, in practice this ideal was rarely if 
ever reached-even in slave societies where humans were born into perpetual bondage - see Davis (2014, Ch. 1). Accordingly, it is very unlikely that your enslavement for a mere six months would successfully reduce you to such a state, especially given the clause in the contract that your enslavement would not be so bad as to make life not worth living. (I owe this objection to an anonymous referee from Critical Review of International Social and Political Philosophy.)

17. Of course, libertarianism is not the only theory of rights which claims that rights are fully deontological. So why doesn't this charge that libertarianism radically privileges some values over others also apply to a whole host of other theories? The answer is that the Asymmetrical Value Claim follows not just from the fully deontological character of libertarian rights, but also from the fact that the capacity of choice is the only capacity protected by libertarian rights-there is a single value which is prioritized over all others, and this is the value of choice. While it is true, for instance, that Rawls makes the liberties outlined in the first principle of justice lexically prior to the economic considerations outlined in the second principle, nevertheless these are a wide variety of liberties, each connected to a good life in importantly different ways. What is strange about the Asymmetrical Value claim is not that some things are privileged over others, but what is privileged, and how.

18. To be clear, the argument here against the Asymmetrical Value Claim here is not that one's theory of the right should be derived from one's theory of the good, and that the theory of the good which forms the basis of the libertarian theory of the right is incorrect. Such a reading is understandable, but it misinterprets the argument here in two ways. First, the argument here is not that the Asymmetrical Value Claim is somehow the ultimate, heretofore undiscovered rational basis of libertarianism. It is merely that libertarianism implies the Asymmetrical Value Claim. Second, the argument here is not that one's theory of the right should be derived from one's theory of the good. It is merely that there is some important connection between the right and the good, as indicated by Taylor's thesis. And in fact this weaker claim, that there needs to be some important connection between the right and the good, is endorsed even by the most ardent defenders of the view that the right is prior to the good. Kant (1998) famously claims (as a necessary practical postulate, not a matter of direct proof) that happiness would be the reward of obedience to the moral law (A809/B837). Rawls (1971) devotes extensive space in A Theory of Justice to the congruence of justice as fairness and goodness as rationality (513 and Part III passim). Indeed, even Nozick (1974) himself is at pains, in the neglected Part III of Anarchy, State, and Utopia, to show that the minimal state is 'inspiring as well as right' (ix). The claim I make is not that an adequate theory of the right must be based on an adequate theory of the good, only that an adequate theory of the right should not imply a radically distorted picture of the good; I have argued that Nozick's theory fails that test.

19. I am grateful to anonymous referees from Critical Review of International Social and Political Philosophy for articulating these worries.

20. In evaluating libertarianism, I have emphasized capacities other than the ones centrally related to happiness in order to avoid the misunderstanding that the critique here is implicitly utilitarian. My account is that the libertarian neglects the whole range of capacities, not just the capacities directly related to happiness; it is merely that these capacities are especially relevant for this case. Moreover, one can certainly think that a deontological theory like libertarianism weighs certain values 
improperly-even values related to welfare-without thinking that such a judgment implies that we should abandon deontology itself.

21. Many will argue that the most obvious capacity that is stunted by slavery is the capacity for autonomy. Even if as a slave you were commanded to do the very same activities you would do if you were free, the performance of those actions is not autonomous in the way they would be if you were free. I have a great deal of sympathy for this point; however, I do not pursue it here because any critique using the concept of autonomy is likely to beg the question, since it is a central concept in political philosophy for which the libertarian has a rival conception.

22. This doesn't mean all libertarians accept the Will Theory; for an alternative proposal, see Mack (2000).

23. One might object that even if all of this is correct, Taylor's Thesis and the Interest Theory are nevertheless similar in one crucial way: both presuppose the existence of something valuable independently of what one wills. The worry is that therefore Taylor's Thesis admits the possibility that one can act against another's will in order to preserve one's interests-the essence of paternalist action. The worry here is surely correct in two ways: first, that paternalist action presupposes the existence of something valuable independently of what one wills; and second, that Taylor's Thesis admits the possibility of paternalist action. However, even if one accepts Taylor's Thesis, this falls very short of actually justifying paternalism-there is a large gap between showing that paternalist action is conceptually possible and showing that it is morally permissible. Admitting that something valuable exists independently of what one wills abandons an early bulwark of defense against the advocate of paternalism, but not a very significant one. After all, even stringent antipaternalists like Mill, (1859/2006, Ch. 4) admit the bare possibility of acting against someone's will to further their interests. Such minor concessions then should not cast doubt on one's antipaternalist bona fides.

24. The libertarian may be tempted to argue here that laissez-faire public policy creates so much economic growth that the need for redistribution would itself disappear. But again, making controversial empirical claims such as these means losing a major advantage of Nozick's theory-avoiding the perennial and often unproductive debates about controversial economic matters. It may be objected that empirical commitments have already been brought into the debate concerning when the disaster-avoidance clause would be invoked. However, the strength of Nozick's argument is not in eschewing empirical commitments altogether, but rather in the dialectical advantage it gains from avoiding entanglement with the traditional, specifically economic arguments for libertarianism.

25. I'd like to thank Adam Hosein, Alison M. Jaggar, Joseph Stenberg, Ajume Wingo, and two anonymous referees from CRISPP for their very helpful comments on previous drafts of this paper.

\section{Disclosure statement}

No potential conflict of interest was reported by the author. 


\section{Notes on contributor}

Dan Lowe is a lecturer at the University of Colorado, Boulder. He works primarily on political philosophy, feminist philosophy, and their intersection with moral epistemology.

\section{ORCID}

Dan Lowe (iD) http://orcid.org/0000-0002-8841-0236

\section{References}

Arneson, R. (2010). Self-ownership and world ownership: Against left-libertarianism. Social Philosophy and Policy, 27, 1.

Arneson, R. (2011). Side constraints, lockean individual rights, and the moral basis of libertarianism. In R. Bader \& J. Meadowcroft (Eds.), The Cambridge companion to Nozick's anarchy, State, and Utopia. Cambridge: Cambridge University Press.

Basker, J. (Ed.). (2012). American antislavery writings: Colonial beginnings to emancipation. New York: Library of America.

Cohen, G. A. (1995). Self-ownership, freedom, and inequality. Cambridge: Cambridge University Press.

Davis, D. B. (2014). The problem of slavery in the age of emancipation. New York: Vintage.

Dworkin, R. (1984). Rights as trumps. In J. Waldron (Ed.), Theories of rights. Oxford: Oxford University Press.

Feinberg, J. (1970). The nature and value of rights. Journal of Value Inquiry, 4.

Feser, E. (2005). There is no such thing as an unjust initial acquisition. Social Philosophy and Policy, 22, 1.

Friedman, M. (1962). Capitalism and freedom. Chicago: University of Chicago Press.

Hooker, B. (2003). Ideal code, real world: A rule-consequentialist theory of morality. Oxford: Oxford University Press.

Huemer, M. (2013). The problem of political authority: An examination of the right to coerce and the duty to obey. New York: Palgrave Macmillan.

Huemer, M. (2015). America's unjust drug war. In R. Shafer-Landau (Ed.), The ethical life: Fundamental readings in ethics and moral problems (3rd ed.). Oxford: Oxford University Press.

Kant, I. (1998). Critique of pure reason (Trans. and edited by Paul Guyer and Allen W. Wood). Cambridge, MA: Cambridge University Press.

Kramer, M., Simmonds, N. E., \& Steiner, H. (1998). A debate about rights. Oxford: Oxford University Press.

Kuhn, T. (1962). The structure of scientific revolutions. Chicago: University of Chicago Press. Kymlicka, W. (2002). Contemporary political philosophy: An introduction (2nd ed.). Oxford: Oxford University Press.

Lippert-Rasmussen, K. (2008). Against self-ownership: There are no fact-insensitive ownership rights over one's body. Philosophy and Public Affairs, 36, 1.

Locke, J. (1980). Second treatise of government. Indianapolis, IN: Hackett.

Mack, E. (2000). In defense of the jurisdictional theory of rights. Journal of Ethics, 4, 1.

Mack, E. (2002). Self-ownership, Marxism, and egalitarianism: Part I: Challenges to historical entitlement. Politics, Philosophy, and Economics, 1, 1. 
Mill, J. S. (1859/2006). On liberty. London: Penguin.

Murphy, L. B., \& Nagel, T. (2002). The myth of ownership: Justice and taxes. Oxford: Oxford University Press.

Nozick, R. (1974). Anarchy, state, and Utopia. New York: Basic Books.

Okin, S. M. (1989). Justice, gender, and the family. New York: Basic Books.

Otsuka, M. (2003). Libertarianism without inequality. Oxford: Oxford University Press.

Quine, W. V. O. (1951). Two dogmas of empiricism. The Philosophical Review, 60, 1.

Rand, A. (1961). The virtue of selfishness. New York: Signet.

Rawls, J. (1971). A theory of justice (Original Edition). Cambridge, MA: Belknap Press.

Rothbard, M. (2002). The ethics of liberty. New York: NYU Press.

Sandel, M. (2009). Justice: What's the right thing to do? New York: Farrar, Strauss and Giroux.

Sinnot-Armstrong, W. (1999). Begging the question. Australasian Journal of Philosophy, $77,2$.

Sobel, D. (2012). Backing away from libertarian self-ownership. Ethics, 123, 1.

Steiner, H. (1994). An essay on rights. Oxford: Blackwell.

Steiner, H. (2013). Directed duties and inalienable rights. Ethics, 123, 2.

Taylor, C. (1985). Philosophy and the human sciences: Philosophical Papers 2. Cambridge: Cambridge University Press.

Thomson, J. J. (1992). The realm of rights. Boston: Harvard University Press.

Vallentyne, P., \& van der Vossen, B. Libertarianism. Retrieved July 1, 2014, from http:// plato.stanford.edu/entries/libertarianism/

Vallentyne, P., Van der vossen, B., Steiner, H., \& Otsuka, M. (2005). Why leftlibertarianism isn't incoherent, indeterminate, or irrelevant: A reply to fried. Philosophy and Public Affairs, 33, 2.

Wolff, J. (1991). Robert Nozick: property, justice, and the minimal state. Stanford, CA: Stanford University Press.

Wolff, R. P. (1981). Robert Nozick's derivation of the minimal state. In J. Paul (Ed.), Reading Nozick: Essays on anarchy, state and Utopia. Totowa, NJ: Rowman and Littlefield. 